\title{
Aluminum Sulfate
}

National Cancer Institute

\section{Source}

National Cancer Institute. Aluminum Sulfate. NCI Thesaurus. Code C75770.

An aluminum salt of sulfuric acid, an industrial chemical used in many industrial applications. In purification of drinking water, aluminum sulfate acts as a flocculating agent which causes impurities to coagulate and sediment, so that they are easily removed by filtration. It is also used as a mordant in textile dyeing and paper manufacture. 